\title{
THE TRAUMATIC CONFRONTATION WITH IDEOLOGY AND THE REAL IN E.L.DOCTOROW'S "WELCOME TO HARD TIMES": A ŽIŽEKIAN STUDY
}

\author{
Hojatallah Borzabadi Farahani ${ }^{1}$ \\ Maryam Beyad ${ }^{2}$
}

\begin{abstract}
Social reality in its essence is political, and any exploration of it needs a political performance. Concerning the issue, literature, by and large, has gained a political function through history. It has been an efficient political device to represent the role and the impact of ideology on the way of living and identity of people. E. L. Doctorow's novels in general, and his Welcome To Hard Times in particular approve of the author's interest in the ideological constitution of American society and the inevitable confrontation of the people with the intrusion of the Real [a Žižekian term] and the regressive work of ideology. In the light of Žižekian perception of the word, ideology is a form of socio-political philosophy in which practical elements are as prominent and decisive as theoretical
\end{abstract}

ones. To him, ideology is a set of ideas licensing social actions and allocating subjects predetermined Symbolic Orders within the context of elusive reality. It gives them a social mandate, and a specific identity to deal with the worldly affairs. However, in Doctorow's Welcome to Hard Times we come to a community of figures, marginal though, who take a rebellion action against ideology to alter the given identity employing their [personal] acts. The present study aims at exploring this reformative attempt on part of the people involved in ideological restrictions.

Keywords: The Real, Symbolic Order, Ideology, Subject, Social reality

\section{Introduction}

Edgar Lawrence Doctorow (1931-2015, New York City) is one of the most accomplished and eminent

\footnotetext{
${ }^{1}$ Faculty Member, Department of English Language, Arak Branch, Islamic Azad University, Arak, Iran*Corresponding Author Email:n_bfarahani@yahoo.com. ${ }^{2}$ Associate Professor, Department of English Language and Literature, University of Tehran, Tehran, Iran. Email: msbeyad@ut.ac.ir.
} 
authors of the $20^{\text {th }}$ century. He has written eight novels (Welcome to Hard Times the first one in the sequence) all the result of his vast amount of westerns he read after his military service. His works are particularly admirable for their synthesis of fiction and history.

No need to say, applying psychoanalytic study on E.L. Doctorow's novels bears benefit since it reveals the unconscious aspect of utterance out through the analysis of characters, relations, and situations. Mostly, psychoanalysts work on the matter of identity and the way of its construction in their studies of one's character. They state that constructionism asserts the process of understanding oneself, others, and reality which are presented in the contextual network of Doctorow's novels, especially in Welcome to Hard Times. Such a view supports the idea that human beings if not constructing new things, but are transforming reality. Though sounds noticeable, this idea misses the crucial point that the depiction of the world we read of in the novel is the representative of a real ideological system in which distinct discourses are involved. So testing a methodology that covers the psychological and political
467

elements all together seems essential. Concerning the point, the present study is to apply Slavio Žižek's dynamic and complex theories. It intends to offer a comprehensive approach that helps the readers to perceive how ideological factors and Psychological responses are decisive in the identity formation of man. Moreover, the notion and the functionality of ideology in Doctorow's novel, Welcome to Hard Times will be examined to reveal first the mechanism of dominant ideology on [the] characters' way of behaving and then the practicable act they do against such ideological dictates.

As John D. Jost states: "ideology is the most elusive concept in the whole of social science" $(2009,308)$. Jost's words imply the fact that 'ideology' in its essential ambiguity signifies different meanings. In this regard, Ryan states that ideology is "a body of ideas that licenses, enables, and directs social action" $(2010,40)$. It also applies to "mistaken cognition that prevents people from seeing reality" as it is (41). In other sense, ideology appears as a set of "ruling ideas forced into a position of centrality by ruling social groups" to reinforce their power (44-5). 


\section{Žižekian concept of ideology}

ŽIŽEK's contribution in defining 'ideology' is derived from Marx's slogan “they do not know it, but they are doing it" $(1995,28)$. Here, the point is a kind of simplicity or ignorance of the reality in which we live. On the one hand there is reality, but on the other hand is our distorted understanding of it. In this sense, ideology is that distortion, that twisting of our perception of reality that we follow every day though we know sufficiently of its incorrectness. As Žižek states, following the German theorist Peter Sloterdijk (b. 1947), "we are cynical subjects" (quoted in Myers, $65)$.

As cynical subjects well enough, we know that what is presented of reality is not correct, yet we welcome that falsehood and do not reject it. Modifying Marx's formula for ideology, Sloterdijk proposes a cynical variation of it _ "they know very well what they are doing, but still, they are doing it” (29). For Žižek, trying an act, that one that continues in spite of knowing its falsity, constitutes "the ideological illusion" (67). The ideological mystification, as Žižek argues, does not lie in the 'knowing' but in 'the doing'; it lies on

\section{8}

the side of misperceiving the reality of its actual situation.

Ideology, put it differently, primarily is related to the 'doing' rather than the 'knowing'. In fact, the illusion or distorted perception of reality is indexed in the situation, and it is the very illusion that structures ideology. Žižek's elaboration on Slotrerdijk's formula reads in this way: "They know that, in their activity, they are following an illusion, but still, they are doing it" (67). In other words, we are ideologies in practice.

Perhaps the most innovative contribution of Žižek in the formulation of ideology is this very implicit assertion that our beliefs or convictions are not what we feel/think but instead what we do. Put it another way, our most intimate/internal sensation is just materialized in our social activity. This materialization of activities is, argues Žižek, the same to how Tibetan prayer needs work:

You write a prayer on a paper, put the rolled paper into a wheel, and turn it automatically, without thinking. In this way, the wheel itself is praying for me, instead of me- or more precisely, I myself am, praying through the medium of the wheel. The 


\section{Direite}

Periódico do Núcleo de Estudos e Pesquisas sobre Gênero e Direito

Centro de Ciências Jurídicas - Universidade Federal da Paraíba V. 9 - $\mathrm{N}^{\mathrm{o}} 02$ - Ano 2020 ISSN | 2179-7137 | http://periodicos.ufpb.br/ojs2/index.php/ged/index beauty of it all is that in my psychological inferiority I can think about whatever I want, I can yield to the most dirty and obscene fantasies, and it does not matter, because-to use a good old Stalinist expression-whatever I am thinking, objectively I am praying (1995, $31-2)$.

\section{Ideology and the Matter of}

\section{Subjectivity in Doctorow's Welcome}

\section{to Hard Times}

Back to Doctorow's novel, in Welcome to Hard Times, we read of the conductive dictates of the prominent discourse of the American ideology which sets in motion the moping mass of people who come to West searching a socalled better life which is basically codified under the name of the American dream.

When I came West with the wagon, I was a young man with expectations of something, I don't know what. I tar-painted my name on a big rock by Missouri trailside. But in time, my expectations wore away with the weather, like my name had from that rock, and I learned it was enough to stay alive (WHT 6). The people, forming a spectrum of different nationalities (English, Chinese, Russian), sexes, and races, are all in a rush to practice the doctrinal rituals of Capitalism; of course, in the shadow of the illusory liberalism. A community of emigrants imagine themselves as free individuals on the way to look for a trade in the vast vacant of harsh West. For instance, such an attempt is to be done even though it turns to be frustrating to Zar and his stock in trade, the whores.

So what shall I do know? All morning I search for a trail to mining camp! You did not tell me there was none; you said nothing. And now I have women who should be on their back, and they are on neck. Four days have I lost! (45)

Staying with Žižek, by subscribing to the rituals of the ideology in action; that is, to go after wealth and treasure, the quester in West believe in 'no' thing before knowing what they do, and in this way, they convert to its doctrinal principles. What happens in continuation is that they follow to respond to and support all the ideological state apparatuses; first to set up towns here and there and then they run business, banks, bars, families and whatsoever. The illusion of what the citizens are engaged in and the disillusionment of the very illusion that 
they believe before believing, as Žižek asserts, are comprehensibly reflected in Blue's words, while he is talking about himself and Mr. Maple.

I couldn't understand his feelings. A man doesn't go West for nothing. He'd been traveling four or five weeks, by train, by steamer, by stage, thinking all the while to find his brother when he got there. And probably to make life (76).

I kept thinking; I was traveling to no purpose. What good was this to that woman and that boy? What could I hope to do for them? Only a fool would call anywhere in this land a place and everywhere else a journey to it (66).

Like the other novels, in Welcome to Hard Times besides picturing the submissiveness of the people to the current socio-political discourse, Doctorow leaves room for the marginal figures to practice their defiance against the centralized ideology the big Other or, in terms of Žižekian psychoanalyses, as a gesture of reviving their subjectivity. One of these marginal characters, interestingly of the female sex, is a woman by the name of Molly who nearly from the beginning up until the end of the novel manages to take actions to reject the dominant Symbolic
470

Order. To pinpoint her personality, as a distinct individual, it needs to see what subjectivity/self means to Žižek.

\section{Žižek's The Ticklish Subject} begins with his assertion that "a spectre is haunting Western academic..., the spectre of the Cartesian subject" (Žižek, 1999, 1). Against the post-structuralist perception of subject, as Derrida puts it, “merely a function of language" (1973, 145) a symbolic machine which is destined to speak the discourse of the big Other, Žižek's reading of the Cogito is more matched with Descarte's method. In Žižek's terminology, we can transform from beings immersed in nature (objectivity) to beings supported by culture (subjectivity). For Žižek, the connecting chain between these two poles is the Cartesian doubt. His definition of the doubt reads: "a withdrawal into self' (Myers, 2003, 36). As Žižek states, this total withdrawal is one of madness, representing the madness of Hegel's 'night of the world':

This night, the inner of the nature, that existed here_pure self_in phantasmagorical representations, is night all around it, in which here shoots a bloody head_there another writes ghastly apparition, suddenly here before 
it, and just so disappears. One catches sight of this night when one looks human beings in the eye_ into a night that becomes awful (quoted in Žižek, 1998, 258).

Another way put, it is only when the world is experienced as a loss or absolute negativity that it becomes necessary to constitute a symbolic universe. Drawing on Žižekian Cogito, the subject is not a substantial I but a void, an empty point of negativity and emptiness that makes the transition from objectivity to subjectivity.

Within the circular shape of the novel, beginning with and ending in fight and destruction, everything and everyone is understood based on the role he/she takes in the Symbolic Order of the forming society. Everything in its symbolic function seems to be in harmony and coherence with the chain of signification. The course of events goes on peacefully up until the traumatic event happens: the premature, unexpected arrival of the Bad Man from Bodie that suddenly breaks through the town.

Given that our knowledge of the world is mediated by language, that we never know anything directly, just through [the] symbols, then the Real is any aspect of life which is left unknown, which escapes and "resists symbolization" (Myers, 2003, 25). Lacan understands the Real as 'absolute beings' or 'being-in-itself'. As such, the Real is opposed to the imaginary and the symbolic, since it is "beyond the realm of appearance and images"; it is "an indivisible brute materiality that exists prior to the symbolization" (Homer, 2005, 82). The other point concerning the Real is that, whatever it is, it is associated with the concept of trauma. For Lacan, trauma is Real insofar as "it remains unsymbolizable and is a permanent dislocation at the very heart of the subject.

As aforementioned, the coming of the Bad Man is considered, concerning the notion of Real, as a traumatic presence to all dwellers in Hard Times, especially to Molly who pictures one of the victimized subjects. Through the narrative, Doctorow expresses some unsymbolizable features of the Real/Bad Man.

[Blue] I guess Florence had never seen, a man so big (WHT 2).

Jack Millay told me later he followed the boy across the street to fill Fee in on the details-little Jimmy might 
not have made it clear that the customer was a Bad Man from Bodie (3).

The Bad Man was celebrating the new day riding bareback and forth from one end of the street to the other (9).

The Bad Man drank Avery's liquor like water and every time he poured for us too.

He was a younger man than I expected, and he had the eyes of a crazy horse. Right then my hand began to move, and I meant for it to go for my gun. But it went instead for the glass on the bar; I felt at that moment that I wanted to please him, I was almost glad to drink (17).

[Molly] Oh, sure! Christ that Bad Man's the only man in town! (75)

From a different angle, the Real/big Other appears to be the fullness of things that the Symbolic Order goes to work on, chopping it up to pieces, yet it remains there; the Real is left over when the Symbolic has finished. In other words, the Real/big Other comes after the symbolization. Likewise the ignored presence of the Bad Man, either before or after the establishment of civility in Hard Times, can be regarded as the unsymbolized ever-presence of the Real on part of the subjects/ the citizens. The frequency of the Bad Man's visits to town and his annihilating roaming the West mirror up his indivisible precedency and his traumatic effect. In fact, whatever happens, it occurs within the ever-lasting presence/intrusion of the Bad Man.

The psychological trauma refers to the events, like the train crashes, that affect and disturb the people either involved in or present or watching the disasters. The most common form of such trauma is either physical or sexual abuse. In Welcome To Hard Times, the Bad Man's unwanted presence is along with both physical and sexual violence. It includes not only men but women, not only one individual but all townspeople. As a psychical event that disturbs the smooth running of the Symbolic signification, trauma "arises from the confrontation between an external stimulus", name it a stranger who receives no name, no land, no thing, and “the subject's inability to understand and master these excitations" (Homer, 2005, 83).

"You're alright, Molly", I said

But when she walked up to the doors, the stiletto slipped out of her sleeve and clattered on the porch. I 
kicked it aside before the Bad Man might see it and I pushed Molly through the doors and stepped in behind. Then I saw what made her drop the knife, Florence bent over

the upstairs railing, bare, with her arms dangling and her red hair falling down between them (WHT 16).

Drawing from Homer's exploration of the Real as "a kind of ubiquitous undifferentiated mass from which we as individual subjects must distinguish ourselves through the process of symbolization" (Homer, 83), getting away from it through reforming a new Symbolic identification seems essential to [the] reformation of one's subjectivity or self.

Keeping a gap between the Real and the Symbolic, for Žižek, enables the subject to experience the crucial transition from a state of nature/object to that of culture/ subjectivity. The indispensible inclusion of the Bad Man as a microcosmic representative of the ruling ideology, something that precedes thought and language, works as a driving force pushing the characters either to a submissive obedient Symbolic role or toward a reformative subjectivization. Molly is one of the rarities who decides to take an intermediate state in her relation with the big Other/Bad Man. She undertakes the Hegelian madness, 'night of the world'. Molly introduces herself as a missing link, or a "vanishing mediator" (Myers, 37) between the two states. She tries [the] transition first by escaping from the Real, to be able to construct a substitute for it to redefine her 'identity'. Her madness depicts a precondition for her sanity as a civilized subject. From the very beginning, she manages to get free, stand away, or even be spiteful to the Bad Man. Molly's paradoxical antagonistic yearning for the Bad Man is understood as her distinct stratagem to redefine her 'subjectivity' with the Real.

It was a celebration. Avery, Jack Millay and I stood at the bar while the man poured for us. Molly sat at one of the tables staring up at Flo with her Knuckles in her mouth. She sat looking away from him. (WHT 17)

"Blue"! Molly screamed. She was trying to put tables and chairs between them and

the Bad Man was laughing and tossing the furniture aside. Molly was struggling and pulling, or I'm sure he would have killed me (18).

In this reading, the self is what Žižek defines as "the center of narrative 
gravity $(1998,261)$, what fills in the void of the subject, and while the subject stays unchanging, the self is open to constant revision.

The non-restrictive joyful ruins the Bad Man brings about if we see him as the voice of the unbeknown ideology, is regarded as the return of the superego. In the permissive society wherein he satisfied his needs and desires, a society continually responding and even inviting to sexual enjoyment, it cannot be right anymore to consider sexual pleasure as something being prohibited. According to Žižek, in this social context, "sensual gratification has been elevated to the status of an official ideology" (Myers, 2003, 53). Put it another way, all people are expected to indulge themselves in enjoyment; they are required to live less and less with law and more and more with superego.

Being located, argues Lacan, in the Symbolic Order, the superego keeps a close but ambiguous relation to the law. As the law is founded upon "the prohibition of incest" (Lacan, 1992 [1986], 67) that which it seeks to exclude, the desire to break and transgress the law is the very precondition for the existence of the law itself. "The superego is the imperative of
jouissance-Enjoy!” (Lacan, 1998 [1975], 3). It is both the law/oedipal father and its agent of destruction/the primal father. These two fathers are involved in the novel. While Blue takes the role of the public law, which is suppressive in its work, the father who transmits the code of law to his people even his child- Jimmy, the Bad Man pictures the primal father, the figure of the absolute father who aggregates to himself the women and wealth by excluding his sons or rivals. $\mathrm{He}$ is the dark side of the law that in his nature is cruel and licentious. As Žižek puts, he emerges at the point where the law fails, and at this point of failure, the law is compelled "to search for support in an illegal enjoyment" (1994, 54).

[Blue] I said trying to control my voice.

What do you say to working in Isaac's store? It will be good for you. You're going to work regular hours. You're going to learn reading and writing. You're going to grow up proper with this town and the day will come (WHT 162).

I pulled him [Jimmy] down. I took hold of his shoulders and held him down on the rocks. "What kind of mama's boy are you! Listen to me: I said 
the day is coming when no man from Bodie will ride in, but he will wither and dry up to dust. You hear me? I'm going to see you grow up with your mind, I'm going to see you settle just like this town, you are going to be a proper man and not some saddle fool wandering around with his grudge.

Jimmy listens to me" (162).

In relation to what mentioned above, while the law is the renunciation of enjoyment reflected in telling what we cannot do, the superego commands us to enjoy what we can do. Staying with Žižek, the superego "marks a point at which permitted enjoyment, freedom-toenjoy, is reversed into an obligation to “enjoy'" (Žižek, 1991, 237). And when enjoyment becomes obligatory, it is no longer fun. Doctorow's novel pictures the same idea having the Bad Man get through the town killing, drinking, and having sex, quite disrespecting the common law which is newly established. In this interpretation, the Bad Man is the caricaturized representative of disturbing radical exercise of the ordered official pleasure. The way he treats his desire for pleasure hypnotizes so many other people to do the same, that is,

they follow him as a model. Now "enjoyment is not an immediate,
475

spontaneous state but is sustained by the superego imperative" (Žižek, 1997, 173). Nearly every man is compelled to adopt a miniaturized version of the Bad Man; that is, he/ she has to follow the same ideological belief from which no escape is thinkable.

And with all that misery in such small space, I thought for one second to get up and get out of there and ride away fast. But I could no more do that than Fee and Flo and the others could get up from their graves- the Bad Man had fixed us all in the spot, and he had fixed me by leaving me alive (WHT 30).

The other impact of the superego to 'enjoy!' is to make its subjects indifferent and unable to enjoy what they are forced to do. Apparent evidence of such neutrality is perceptible in Molly. Being a professional whore, making a living with prostituting herself to the tradition of the saloon and the bargoers, after the compulsory sex with the Bad Man, she not only becomes for a while indifferent to the profession but feels disgusting it also.

I stepped inside to see if Molly was awake. Slits and speckles of light lay across the floor, and one strip of light fell on her open eyes. She looked bad. Her face was so thin I could see how the 
bones and blue veins went under her skin. The food beside her was untouched. I didn't know what I should say to her. I didn't know what she would say to me (WHT 33).

But I looked at her and saw what a sweet smile it was, full of hate, and I felt as if I had been swiped to the ground by the paw of a big cat (34).

The woman in John Bear's shack was no longer Molly; what had happened in Avery's saloon could never be undone (34).

“Don't you touch me?” Molly screamed. "Whores! Keep away from me!'(41)

To the dismay of the Bad Man, and the freedom he propagates, Molly adopts a transgressing attitude towards life which is manifested in her sobriety, aloofness and pride about Blue, and she takes a sadomasochistic position to the Bad Man as the only way left to pleasure under the injunctions of the superego.

Molly, all streaked with tears and dirt, looked up at Jimmy as if seeing him for the first time.

I was wishing she could look at me that way (43).

It was to plague me for a long time that I couldn't tell what she would answer, or I might find a moment's favor in her eyes. She didn't say

anything till I began to wonder if she $d$ heard me (60).

Within the elemental feature of the Real/big Other, resisting symbolization, sets the notion of its disintegration. What Žižek means is that the big Other has always been dead in the sense that it never existed in the first place as a material thing. For Žižek, all it ever was is just symbolic or fictional order, another way put, we are all "engaged in a minimum of idealization, disavowing the brute fact of the Real in favor of another symbolic world behind it" (Myers, 50). As human beings, we have to engage in the loop of symbolization and help it move on to forget the abyss of the Real though factually we know that it is nothing more than a kind of fib or lie. If there is a loophole to get rid of the ceaseless course of symbolization, it is through an 'act'.

An 'act' signifies, in Žižekian terminology, the re-birth of the subject. It means a perfect rejection of the present Symbolic Order and mandate/role assumed by the subject. As Žižek states: The act differs from an active intervention /action. In that it radically transforms its bearer/ agent: the act is not 
simply something I 'accomplish'_ after and act, I am literally 'not the same as before'. In this sense, the subject undergoes the act (passes through it) rather than accomplishes it: in it, the subject is annihilated and subsequently reborn (or not), i.e., the act involves a kind of temporary eclipse, aphanisis of the subject $(2000,44)$.

Accordingly, it is attempting madness to withdraw from the world, risking not only any possible return but any other point to back to. Therefore, 'act' is putting oneself in danger to commit a Symbolic suicide.

The inconsolable death-wish Molly wishes on the Bad Man on the one hand, and on the other hand, Blue's unrequited love, loving Molly due to her enigmatic way of behavior that through the course of events makes a submissive man of him draws them both, Molly and Blue, toward their suicidal act at the end of the novel.

That was the idea I -Blue- held on to like my life, it moved me to action, it was a clear simple thought and I took it over from Jenks, becoming the fool he'd been, lifting the fool's hat from his dead body to fit on myself, becoming Molly's final fool, as I am now (WHT 197-98).
After shooting the Bad Man down and clubbing him to be insensible, Blue carries him home half dead, drops him on the table. Then both Molly and Blue fulfill their own gesture of avenge on the Bad Man, the man of their dream. Molly, quite excited, jabs him, the great insulter with her stiletto as a way of retaliating his insults till she grabs him in arms to initiate a unity. Blue, on his part, shoots them, Molly and the Bad Man, dead to be no more eclipsed with their Symbolic mandate. Though Molly and Blue's gestures are different in form, the effect is identical since it helps them both to reinvent a new symbolic identification with the Real / the Bad Man. Molly steps toward a negating union in her symbolic embrace with the Bad Man, to be killed and so protect the dignity of her own 'self' as a 'woman' within the existing Symbolic (of patriarchy) and the mandate of the corresponding ideology. Blue's final hysteric gesture, to shoot the Bad Man, aligns with killing off Molly, the one who is the dearest and most wanting to him; this action, in one sense, enables Blue both to massacre the rival and the woman he holds the dearest. This act, as Žižek argues, "far from amounting to a case of impotent aggressivity turned against oneself, 


\section{Direite}

Periódico do Núcleo de Estudos e Pesquisas sobre Gênero e Direito

Centro de Ciências Jurídicas - Universidade Federal da Paraíba

V. 9 - $\mathrm{N}^{\mathrm{o}} 02$ - Ano 2020

ISSN | 2179-7137 | http://periodicos.ufpb.br/ojs2/index.php/ged/index rather changes the co-ordinates of the situation in which the subject finds himself $(2000,150)$. In one sense, by doing the murder, Blue escapes from the engulfment of the Other, name it either the Bad Man, his rival, or his dearest loved one, Molly.

"All right, Molly? Is it alright now? Is this what you wanted?" But she didn't hear me. She stood as far away as she could and watched me drop him on the table. (WHT 203) Back she jumped and then forward into another place, and he [the Bad Man] tried to writhe away from the point. "Eh?" says Moly. "Eh?" as if to say remember me? Remember your Molly? "Eh?" does this make you remember, or this, or this! -almost dancing with the grace of retribution (204).

It was the moment Turner's arms had closed around Molly as if in an embrace. My hand was over the Muzzle of the gun, but the blast killed them both (205).

\section{Conclusion}

If the order of the Real considered, in Žižekian psychoanalysis, as those areas of life which cannot be known, and if the Symbolic, as Lacan
478

claims, in its function "introduces a cut into the Real" (Myers, 2003, 25), the terms are initially bound with each other. The counterbalance of this intimacy as much as concerned to the notion of [the] subject means the disappearance of [the] subject. Put it differently, the lack of discrepancy between what everything is and what everything means equates the end of the signifying chain. E. L. Doctorow's novel, Welcome to Hard Times, depicts this fundamental mutual bound in the context of the relationship between the involved characters and domineering discourses. The interconnection of the discourses, the voice of ideology with its marginal subjects, reflects the Žižekian contention that what makes us human or more precisely, the thing that makes us 'subject' is the very signifying chain and the decision we make in regard to our mutual relation with the Real or its effects named ideology. Monitoring the destiny of the people in Hard Times who defined themselves in their connection to the Real as automaton, unthinkable obeying subjects to the doctrinal rituals of the Symbolic Order, it is evident that it brought them to nothing except the vanishing of the 'self'. The leading cause of this premature death/ extinction from 
social interaction is their complete submission to the Symbolic, and ignoring the ever intrusion of what lies out of it, the Real. The ever-presence of the Real, represented by traumatic intrusion of the Bad Man, makes some people, few if not all, to decide on their reaction against it. The point is deciding how to cope with this unwanted, but the undeniable presence of the Bad Man they find the occasion of being reappeared as a subject. This reflects Žižek's perception of subject, that "it exists at the interface or on the borders between the Symbolic and the Real" (29).

Adapting the formulas of both Marx and Sloterdijik, on the concept of ideology, Žižek sums up the cynical attitude as "they know very well what they are doing, following an illusion, but they are doing it" (Žižek, 1995, p.29). In this sense, our belief in ideology is staged in advance of our acknowledging that belief in belief machines. Therefore, as we think we have assumed a position of truth from which to denounce the lie of ideology, we find ourselves back in a doctrinal ideology again mainly because truth belongs to the Real that always remains unsymbolized. Moreover, ideology in its effects conceals the failed symbolization of the antagonism of class struggle in the Real. Accordingly, Molly's deep-seated sense of hatred and her intention to stand away from Blue, a man who is perceived as the man of family or the so-called Mayer in the novel, manifests her knowledge on the illusory guise of reality in the form of a peaceful, coherent and integrated society. Such a society for certain is imposed on every man by means of Žižekian belief machines whether named state, family or whatsoever in Welcome To Hard Times.

Žižek's solution to get loose of neutrality of our being and the blinding impact of the dominant ideology is to be able to subject it to critique. To him, the problem with contemporary politics is that it is non-political, that it considers the present capitalist structure of society as natural. Staying with Žižek's idea, the first step to reconstruct the reality/ Symbolic Order is to critique the naturalness of the present state, an attempt which associates reinvention of one's subjectivity with [in] ideology. If we behold the first compulsory confrontation of Molly with the Bad Man that ends in her bodily and physical belittlement, as her recognition unveiling the beguiling function of the ideology which hides the failure of the current 
Periódico do Núcleo de Estudos e Pesquisas sobre Gênero e Direito

Centro de Ciências Jurídicas - Universidade Federal da Paraíba V. 9 - $\mathrm{N}^{\mathrm{o}} 02$ - Ano 2020 ISSN | 2179-7137 | http://periodicos.ufpb.br/ojs2/index.php/ged/index
Symbolic Order, her second deliberate approach to the Bad man (who symbolizes both the unbeknown, unsymbolizable Real, and the spectre of ideology) can be interpreted as her individual attempt to keep the project of ideological critique alive. Put it differently, it is a gesture on part of Molly to take a passage through a political suicidal act to reject what there is - capitalism - to open up a space in which her subject is more entrapped in their paranoid fears and servility pleasures.

\section{References:}

Bertens, Hans (2001). Literary Theory: The Basics. London: Routledge.

Derrida, Jacques (1973).Speech and Phenomena and Other Essays on Husserl's Theory of Sings. (trans. David B. Allison), Evanston: Northwestern University Press. Doctorow, E.L. (1960). Welcome To Hard Times. United States: Simon and Schuster.

Doctorow, E. L. (1960). Welcome to Hard Times. New York: Random House.
480

Homer, S (2005). Jacques Lacan. London and New York: Routledge.

Houdson, Beth (2008). The whole World in a Book: Fact, Fiction, and the Post Modern in Selected Works by E. L. Doctorow, N. P., n. d.

Jost, John D. et al. (2009). Political ideology: Its Structure, functions, and elective affinities. In Annual Review of Psychology, 308.

Lacan, J (1992 [1986]).The seminar of Jacques Lacan, Book VII: The Ethics Psychology 1959-1960, Psychoanalysis ed. J.-A. Miller, trans. D. Porter. London: Routledge.

Lacan, J (1998 [1975]). The seminar of Jacques Lacan, Book XX: Encore, On Feminine Sexuality, The Limits of Love and Knowledge1972-1973, ed. J.-A. Miller, trans. B. Fink, New York: Norton.

Lawrence D. Kritzman (1998). Politics, Philosophy, Culture: Interviews and Other Writing, 1977-1984. New York: Routledge. 
Periódico do Núcleo de Estudos e Pesquisas sobre Gênero e Direito

Centro de Ciências Jurídicas - Universidade Federal da Paraíba V. 9 - $\mathrm{N}^{\mathrm{o}} 02$ - Ano 2020 ISSN | 2179-7137 | http://periodicos.ufpb.br/ojs2/index.php/ged/index
Myers, Tony (2003). Slavoj Žižek.

London and New York: Routledge.

Raja, Masood, Cahill Kevin, and Lene Johannessen (2007). Considering Class: Essays on the Discourse of the American Dream. Münster: Lit.

Ryan, Michael (2010). Cultural Studies: A Practical Introduction. Oxford: Wiley Blackwell.

Wolfreys, Julian, Ruth Robbins, and Kenneth Womack (2006). Key Concepts in Literary Theory. Edinburgh: Edinburgh UP.

Žižek, Slavoj (1991). For They Know Not What They Do: Enjoyment as a Political Factor. London and New York: verso.

Žižek, Slavoj (1994). The Metastases of Enjoyment: Six Essays on Woman and Causality. London: verso.

Žižek, Slavoj (1995). The Sublime Object of Ideology. London: verso.

Žižek, Slavoj (1997). The Plague of Fantasies. London and New York: Verso.
481

Žižek, Slavoj (1998). Cogito and the Unconscious Durkan: Duke University Press.

Žižek, Slavoj (1999). The Ticklish Subject: The Absent Centre of Political Ontology. London and New York: verso.

Žižek, Slavoj (2000). Enjoy Your Symptom! Jacques Lacan. In Hollywood and Out, $2^{\text {nd }}$ edition. London and New York: Routledge.

Žižek, Slavoj (2000). The Fragile Absolute Or Why the Christian Legacy is Worth Fighting For. London and New York: verso.

Žižek, Slavoj (2001). On Belief. New York: Rutledge.

Žižek, Slavoj (2002). Welcome to the Desert of the Real! Five Essays on September 11 and Related Dates. London and New York: Verso.

Žižek, Slavoj (2005). Interrogating the Real. Eds. Rex Butler and Scot Stephens. London and New York: Continum. 
Periódico do Núcleo de Estudos e Pesquisas sobre Gênero e Direito Centro de Ciências Jurídicas - Universidade Federal da Paraíba V. 9 - $\mathrm{N}^{\mathrm{o}} 02$ - Ano 2020 ISSN | 2179-7137 | http://periodicos.ufpb.br/ojs2/index.php/ged/index

Žižek, Slavoj (2006). The Parallax View.

Cambridge, Massachusetts: The MIT

Press.

Žižek, Slavoj (2014). Absolute Recoil:

Or Toward a New Foundation of

Dialectical Materialism. London and

New York: Verso 